\title{
Association between Caffeine Consumption in Pregnancy and Low Birth Weight and Preterm Birth in the birth Cohort of Ribeirão Preto
}

\section{Associação entre consumo de cafeína durante a gestação com baixo peso ao nascer e nascimento pré-termo na coorte de Ribeirão Preto}

\author{
Fernanda Pino Vitti ${ }^{1}$ Carlos Grandi ${ }^{2}$ Ricardo de Carvalho Cavalli ${ }^{3}$ Vanda Maria Ferreira Simões ${ }^{4}$ \\ Rosângela Fernandes Lucena Batista ${ }^{4}$ Viviane Cunha Cardoso ${ }^{1}$
}

1 Department of Pediatrics, Faculdade de Medicina de Ribeirão Preto da Universidade de São Paulo, Ribeirão Preto, SP, Brazil

Address for correspondence Fernanda Pino Vitti, MD, Departamento de Pediatria, Faculdade de Medicina de Ribeirão Preto, Universidade

2 Department of Pediatrics, Facultad de Medicina de la Universidad de Buenos Aires, Argentina

3 Department of Gynecology and Obstetrics, Faculdade de Medicina de São Paulo, Av. Bandeirantes, 3900, Monte Alegre, Ribeirão Preto, de Ribeirão Preto da Universidade de São Paulo, Ribeirão Preto, SP, Brazil

${ }^{4}$ Department of Public Health, Universidade Federal do Maranhão, São Luiz, MA, Brazil

Rev Bras Ginecol Obstet 2018;40:749-756.

\begin{abstract}
Objective To describe caffeine consumption during pregnancy and its association with low birth weight (LBW) and preterm birth in the birth cohort of Ribeirão Preto, state of São Paulo, Brazil, in 2010.

Methods Cohort study, with descriptive and analytical approach. Data included 7,607 women and their newborns in Ribeirão Preto, state of São Paulo, Brazil. The women answered standardized questionnaires about reproductive health, prenatal care, life habits, sociodemographic conditions, and information about coffee intake. The independent variable was high caffeine consumption ( $\geq 300 \mathrm{mg} /$ day) from coffee during pregnancy, and the dependent variables were LBW (birth weight $<2,500 \mathrm{~g}$ ) and preterm birth ( $<37$ weeks of gestational age). Four adjusted polytomous logistic regression models, relative risk (RR) and 95\% confidence interval $(\mathrm{Cl})$ were fitted: biological and sociodemographic conditions; obstetric history; current gestational conditions; and all variables included in the previous models.

Keywords

- caffeine

- pregnancy

- cohort studies

- low birth weight

- preterm birth

Results A total of 4,908 (64.5\%) mothers consumed caffeine, 143 (2.9\%) of whom reported high consumption. High caffeine intake was significantly associated with reduced education and with the occupation of the head of the family, nonwhite skin color, not having a partner, higher parity, previous abortion and preterm birth, urinary tract infection, threatened abortion, alcohol consumption and smoking. No association was found between high caffeine consumption and LBW or preterm birth in both
\end{abstract}

received

May 28, 2018

accepted

September 20, 2018
DOI https://doi.org/ $10.1055 / \mathrm{s}-0038-1675806$. ISSN 0100-7203.
Copyright @ 2018 by Thieme Revinter Publicações Ltda, Rio de Janeiro, Brazil
License terms

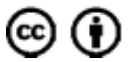




\section{Resumo}

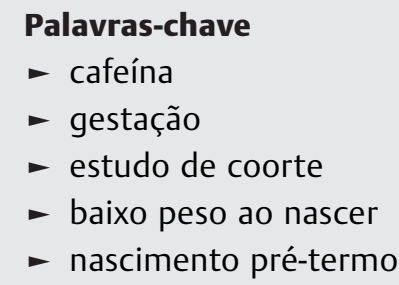

unadjusted $(\mathrm{RR}=1.45 ; 95 \% \mathrm{Cl}: 0.91-2.32$; and $\mathrm{RR}=1.16 ; 95 \% \mathrm{Cl}: 0.77-1.75$, respectively) and adjusted analyses $(\mathrm{RR}=1.42 ; 95 \% \mathrm{Cl}: 0.85-2.38$; and $\mathrm{RR}=1.03$; 95\% Cl: 0.65-1.63, respectively).

Conclusion In this cohort, high caffeine intake was lower than in other studies and no association with LBW or preterm birth was found.

Objetivo Descrever a associação entre consumo de cafeína durante a gestação com baixo peso ao nascer (BPN) e nascimento pré-termo (PT) na coorte de Ribeirão Preto, estado de São Paulo, Brasil, em 2010.

Métodos Estudo de coorte, com abordagem descritiva e analítica. Foram incluídas 7.607 mulheres e seus recém-nascidos em Ribeirão Preto, São Paulo, Brasil. As mulheres responderam a questionários padronizados sobre saúde reprodutiva, cuidados pré-natais, hábitos de vida, condições sociodemográficas e consumo de cafeína. A variável independente foi alto consumo de cafeína ( $\geq 300 \mathrm{mg} /$ dia) durante a gestação e as dependentes foram BPN (peso $<2.500 \mathrm{~g}$ ) e nascimento PT ( $<37$ semanas de gestação). Foram calculados riscos relativos (RRs) e intervalos de confiança (ICs) de $95 \%$ em quatro modelos de regressão logística: condições biológicas e sociodemográficas; história obstétrica; condições da gestação atual; e todas as variáveis incluídas nos modelos anteriores.

Resultados Um total de 4.908 (64,5\%) mães consumiram cafeína, e destas, 143 $(2,9 \%)$ relataram alto consumo. Alto consumo de cafeína esteve associado com menor escolaridade materna, ocupação do chefe da família, cor de pele não branca, mulheres sem companheiro, maior paridade, aborto e nascimento PT anterior, infecção do trato urinário, ameaça de aborto, consumo de álcool e tabagismo. Não foi encontrada associação entre alto consumo de cafeína e BPN ou nascimento PT nas análises não ajustada ( $R R=1,45$; IC 95\%: 0,91-2,32; e $R R=1,16$; IC 95\%: 0,77-1,75, respectivamente) e ajustada ( $R R=1,42$; IC 95\%: 0,85-2,38; e $R R=1,03$; IC 95\%: 0,65-1,63, respectivamente).

Conclusão Nessa coorte, o alto consumo de cafeína foi menor que em outros estudos e não foi encontrada associação com BPN ou nascimento PT.

\section{Introduction}

Maternal exposures, such as excessive caffeine consumption during pregnancy, are likely associated to low birth weight (LBW) and preterm birth. This issue has been the subject of several epidemiological studies. ${ }^{1-4}$ However, the results of these studies are contradictory, which is partly explained by the heterogeneity in study design, by the measurement of caffeine intake, and by the identification of confounders. ${ }^{3,5-7}$

Caffeine (1,3,7-trimethylxanthine), an alkaloid contained in coffee, tea, cocoa, soft drinks with cola, some medications, and stimulants, is a substance generally socially accepted in the whole world that acts as a psychoactive stimulant. ${ }^{1}$ In pregnant women, caffeine passes the placenta freely, where the immature fetal liver enzyme CYP3A4 is unable to metabolize it, ${ }^{8}$ resulting in the accumulation of caffeine in the fetus; ${ }^{9-11}$ substantial quantities of caffeine pass into the amniotic fluid and into the umbilical cord blood, being distributed to all of the tissues of the fetus. Therefore, this may increase the concentration of cellular cyclic adenosine monophosphate (cAMP), interfering in fetal cell growth and development. ${ }^{12}$ Moreover, caffeine causes most of its biological effects via antagonizing all types of adenosine receptors and increasing epinephrine concentrations in the mother and in the fetus, resulting in decreased placental blood flow and hypoxia. ${ }^{13}$

Studies showed that the amount of caffeine intake during pregnancy is relatively high. The prevalence in women who had preterm birth was $68.1 \%,{ }^{5}$ whereas, in Brazil, the prevalence was $75 \%$ during pregnancy. ${ }^{14}$

Several studies showed an increased risk of adverse perinatal outcomes when caffeine consumption was $\geq 300$ $\mathrm{mg} / \mathrm{day},{ }^{1,9,15}$ between 150 and $300 \mathrm{mg} / \mathrm{day},{ }^{16}$ or $<150 \mathrm{mg} /$ day. ${ }^{5}$ Other studies did not find any association, ${ }^{17,18}$ but most of the studies consider high caffeine intake as $\geq 300 \mathrm{mg} /$ day. ${ }^{1,9,15,19-22}$

In Ribeirão Preto, state of São Paulo, Brazil, a birth cohort started in January 2010, which included 7,702 mothers and newborns (NB) in facilities right after childbirth. Cohort studies are considered paramount in understanding the 
effects of intrauterine life and of childhood conditions on adult health. ${ }^{23}$

Thus, the objectives of the present study were to describe caffeine intake during pregnancy and estimate the risks between high caffeine consumption with LBW and preterm birth, on the 2010 birth cohort of Ribeirão Preto, state of São Paulo, Brazil.

\section{Methods}

This cohort is part of the Brazilian Ribeirão Preto and São Luís Birth Cohort Studies (BRISA, in the Portuguese acronym,), with the main objectives of evaluating new preterm birth risk factors (neuroendocrine, immunoinflammatory, and medical intervention hypothesis), perinatal health indicators, and impact on later preterm birth growth. The cohort included 7,702 mothers and their NBs between January $1^{\text {st }}$ and December $31^{\text {th }}, 2010$; 95 twin pregnancies were excluded, remaining 7,607 mothers and NBs evaluated.

Childbirth took place in eight maternity hospitals of Ribeirão Preto and, during the study period, trained personnel visited these facilities to interview the mothers and collect information about the NBs from medical records.

The dependent variables were low birth weight (LBW) (birth weight [BW] $<2,500 \mathrm{~g}$ ) and preterm birth (gestational age $<37^{+0}$ weeks), and the independent variable was caffeine intake (only from coffee). Information about daily and weekly frequency of caffeine consumption during each trimester of gestation (days/week), and type of container used were collected. No information about tea, chocolates, sodas and other sources of caffeine were recorded. Caffeine consumption from coffee during pregnancy was categorized as none, low ( $<300 \mathrm{mg} /$ day) and high ( $\geq 300 \mathrm{mg} /$ day), according to the Care Study Group. ${ }^{24}$ The daily frequency of caffeine consumption in milliliters was calculated by multiplying the daily quantity (times/day) by the daily frequency (days/week) and the type of container ( 50 or $200 \mathrm{ml}$ ) in each trimester. Then, the result was divided by 7 days of the week. Since $125 \mathrm{ml}$ of coffee corresponded to $90 \mathrm{mg}$ of caffeine, ${ }^{7}$ each $\mathrm{ml}$ of coffee intake contained $0.72 \mathrm{mg}$ of caffeine.

The questionnaires included mother variables (demographic, social and reproductive health, life habits, pregnancy complications, and coffee intake) and NB variables (gender, BW, gestational age [GA], morbidities, and stillborn). Newborn anthropometry included BW and length.

Maternal age was categorized as $\leq 19$, between 20 and 34 , and $\geq 35$ years old. Maternal education was categorized as $\leq$ 8 , between 9 and 11 , and $\geq 12$ years of study. Skin color was self-referenced as either white or not white. Marital status was categorized as with or without partner. The occupation of the head of the family ${ }^{25}$ was categorized as no manual, qualified, semi qualified, and not qualified workers. Parity was categorized as 1 , between 2 and 3 , and $\geq 4$ childbirths. Information was collected regarding previous preterm birth, abortion, and stillbirth; hypertension, diabetes, urinary tract infection and odontological treatments during pregnancy; threatened abortion and preterm delivery; as well as alcohol consumption and maternal smoking.
For improving the presentation of the results, we followed the strengthening the reporting of observational studies in epidemiology (STROBE) initiative. ${ }^{26}$

Data analysis included mean (standard deviation [SD]), median (interquartile range [IQR]) or proportions (95\% confidence interval $[\mathrm{CI}])$. A univariate risk analysis between LBW and preterm birth, high caffeine consumption and covariates were performed. Then, four adjusted polytomous logistic regression models (relative risk [RR] and 95\% confidence interval $[95 \% \mathrm{CI}]$ ) were fit. The first one was adjusted for biological and sociodemographic conditions (age, maternal education, skin color, marital status, occupation of the head of the family); the second included obstetric history (parity, previous preterm birth, abortion and stillbirth); the third was adjusted for current gestational conditions (gestational hypertension and diabetes, threatened abortion and preterm delivery, alcohol consumption, maternal smoking, urinary tract infection, and odontological treatments during pregnancy); and the last was adjusted for all variables included in the previous models. The reference value was the absence of caffeine consumption. The goodness of fit was tested using the Hosmer-Lemeshow test. All analyses were performed with Stata software, version 13.0 (Stata Corp., College Station, TX, USA) and SAS software, version 9.2 (SAS Institute, Cary, NC, USA). Statistically significant difference was set at $p<0.05$. The present study was approved by the Research Ethic Committee of the Ribeirão Preto Medical School of the Universidade de São Paulo (process $n^{\circ} 10400 / 2012$ ), and all participants received and signed the informed consent form.

\section{Results}

A total of 7,607 mothers and their NBs were included. Of these, 4,908 (64.5\%; 95\% CI: 63-65) consumed caffeine from coffee during pregnancy, 143 of whom (2.9\%; 95\% CI: 25-34) ingested $\geq 300 \mathrm{mg} /$ day. The mean BW was $3,143 \mathrm{~g}$ (SD $=553$ ); $8.7 \%$ were LBW, and $1.7 \%$ were very low birth weight (VLBW $[<1,500 \mathrm{~g}]$ ). The mean GA was 285 (SD = 104) days, and $14.5 \%$ of the childbirths were preterm ( $<259$ days).

The majority of the total population studied ingested up to $500 \mathrm{mg}$ of caffeine per day, with a median caffeine intake of $91.5 \mathrm{mg} /$ day $(\mathrm{IQR}=143.8)$; there was no difference per trimester of caffeine intake (data not shown).

High caffeine intake was significantly associated with reduced maternal education, occupation of the head of the family, nonwhite skin color, and not having a partner (-Table 1).

High caffeine intake was significantly associated with higher parity, previous abortion and preterm birth, urinary tract infection, threatened abortion, alcohol consumption, and smoking (-Table 2 ).

Low birth weight was the only condition significantly associated with high caffeine consumption (-Table 3 ).

Crude risks for LBW and preterm birth were 1.45 (95\% CI: 0.91-2.32) and 1.16 (95\% CI: 0.77-1.75), respectively. For LBW, the RR increased slightly after the adjustment, but no differences were observed ( - Table 4 ). For preterm birth, the RR decreased slightly after the adjustment in the four 
752 Association between Caffeine Consumption in Pregnancy and Low Birth Weight Vitti et al.

Table 1 Selected sociodemographic maternal characteristics of the Ribeirão Preto Birth Cohort of 2010 in terms of caffeine consumption

\begin{tabular}{|c|c|c|c|}
\hline Characteristic & $\begin{array}{l}<300 \mathrm{mg} / \text { day } \\
n(\%)\end{array}$ & $\begin{array}{l}\geq 300 \mathrm{mg} / \text { day } \\
n(\%)\end{array}$ & p-value \\
\hline \multicolumn{3}{|l|}{ Maternal age (years old) } & \multirow[t]{4}{*}{0.153} \\
\hline $20-34$ & $3,543(74.4)$ & $111(77.6)$ & \\
\hline$<20$ & $526(11.0)$ & $19(13.3)$ & \\
\hline$\geq 35$ & $696(14.6)$ & $13(9.1)$ & \\
\hline \multicolumn{3}{|l|}{ Maternal education (years) ${ }^{*}$} & \multirow[t]{4}{*}{$<0.001$} \\
\hline$\geq 12$ & $1,099(23.6)$ & $8(5.7)$ & \\
\hline$\leq 8$ & $1,197(25.7)$ & $76(54.7)$ & \\
\hline $9-11$ & $2,358(50.7)$ & $55(39.6)$ & \\
\hline \multicolumn{3}{|l|}{ Occupation of the head of the family* } & \multirow[t]{5}{*}{$<0.001$} \\
\hline No manual workers & $711(15.4)$ & $2(1.5)$ & \\
\hline Qualified workers & $702(15.2)$ & $8(5.9)$ & \\
\hline Semi-qualified workers & $2,072(45.0)$ & $68(50.4)$ & \\
\hline Not qualified workers & $1,122(24.4)$ & $57(42.2)$ & \\
\hline \multicolumn{3}{|l|}{ Skin Color* } & \multirow[t]{3}{*}{$<0.001$} \\
\hline White & $2,814(59.5)$ & $56(40.3)$ & \\
\hline Not white & $1,915(40.5)$ & $83(59.7)$ & \\
\hline \multicolumn{3}{|l|}{ Marital status* } & \multirow[t]{3}{*}{$<0.001$} \\
\hline With partner & $4,182(87.8)$ & $105(73.4)$ & \\
\hline Without partner & $581(12.2)$ & $38(26.6)$ & \\
\hline Total & $4,765(100)$ & $143(100)$ & \\
\hline
\end{tabular}

*Excluded cases.

Table 2 Selected obstetric characteristics of the Ribeirão Preto Birth Cohort of 2010 in terms of caffeine consumption

\begin{tabular}{|c|c|c|c|}
\hline Characteristic & $\begin{array}{l}<300 \mathrm{mg} / \text { day } \\
n(\%)\end{array}$ & $\begin{array}{l}\geq 300 \mathrm{mg} / \text { day } \\
n(\%)\end{array}$ & p-value \\
\hline \multicolumn{3}{|l|}{ Parity (childbirths) ${ }^{*}$} & \multirow[t]{4}{*}{$<0.001$} \\
\hline 1 & $2,242(47.1)$ & $41(28.7)$ & \\
\hline $2-3$ & $2,152(45.2)$ & $69(48.2)$ & \\
\hline$\geq 4$ & $364(7.7)$ & $33(23.1)$ & \\
\hline \multicolumn{3}{|l|}{ Previous abortion* } & \multirow[t]{3}{*}{0.023} \\
\hline No & $3,859(81.0)$ & $105(73.4)$ & \\
\hline Yes & $903(19.0)$ & $38(26.6)$ & \\
\hline \multicolumn{3}{|l|}{ Previous preterm birth* } & \multirow[t]{3}{*}{0.003} \\
\hline No & $4,079(86.5)$ & $109(78.4)$ & \\
\hline Yes & $639(13.5)$ & $30(21.6)$ & \\
\hline \multicolumn{3}{|l|}{ Previous stillbirth* } & \multirow[t]{3}{*}{0.404} \\
\hline No & 4,688 (98.4) & $142(99.3)$ & \\
\hline Yes & $75(1.6)$ & $1(0.7)$ & \\
\hline \multicolumn{3}{|l|}{ Gestational hypertension* } & \multirow[t]{3}{*}{0.680} \\
\hline No & $4,163(87.7)$ & $127(88.8)$ & \\
\hline Yes & $586(12.3)$ & $16(11.2)$ & \\
\hline
\end{tabular}


Table 2 (Continued)

\begin{tabular}{|c|c|c|c|}
\hline Characteristic & $\begin{array}{l}<300 \mathrm{mg} / \text { day } \\
n(\%)\end{array}$ & $\begin{array}{l}\geq 300 \mathrm{mg} / \text { day } \\
n(\%)\end{array}$ & p-value \\
\hline \multicolumn{3}{|l|}{ Gestational diabetes* } & \multirow[t]{3}{*}{0.999} \\
\hline No & $4,450(93.7)$ & $134(93.7)$ & \\
\hline Yes & $299(6.3)$ & $9(6.3)$ & \\
\hline \multicolumn{3}{|l|}{ Urinary tract infection* } & \multirow[t]{3}{*}{0.049} \\
\hline No & $3,256(68.6)$ & $87(60.8)$ & \\
\hline Yes & $1,489(31.4)$ & $56(39.2)$ & \\
\hline \multicolumn{3}{|l|}{ Odontological treatments* } & \multirow[t]{3}{*}{0.222} \\
\hline No & $3,315(70.7)$ & $93(66.0)$ & \\
\hline Yes & $1,373(29.3)$ & $48(34.0)$ & \\
\hline \multicolumn{3}{|l|}{ Threatened abortion* } & \multirow[t]{3}{*}{0.049} \\
\hline No & $4,427(93.0)$ & $127(88.8)$ & \\
\hline Yes & $329(7.0)$ & $16(11.2)$ & \\
\hline \multicolumn{3}{|l|}{ Threatened preterm birth* } & \multirow[t]{3}{*}{0.275} \\
\hline No & $4,129(86.9)$ & $119(83.8)$ & \\
\hline Yes & $620(13.1)$ & $23(16.2)$ & \\
\hline \multicolumn{3}{|l|}{ Alcohol consumption* } & \multirow[t]{3}{*}{$<0.001$} \\
\hline No & $3,578(75.1)$ & $86(60.1)$ & \\
\hline Yes & $1,185(24.9)$ & 57 (39.9) & \\
\hline \multicolumn{3}{|l|}{ Smoking } & \multirow[t]{3}{*}{$<0.001$} \\
\hline No & $4,213(88.4)$ & $88(61.5)$ & \\
\hline Yes & $552(11.6)$ & $55(38.5)$ & \\
\hline TOTAL & $4,765(100)$ & $143(100)$ & \\
\hline
\end{tabular}

*Excluded cases.

Table 3 Selected neonatal characteristics of the Ribeirao Preto Birth Cohort of 2010in terms of caffeine consumption

\begin{tabular}{|c|c|c|c|}
\hline Characteristic & $\begin{array}{l}<300 \mathrm{mg} / \text { day } \\
n(\%)\end{array}$ & $\begin{array}{l}\geq 300 \mathrm{mg} / \text { day } \\
n(\%)\end{array}$ & $p$-value \\
\hline \multicolumn{3}{|l|}{ Gender* } & \multirow[t]{3}{*}{0.928} \\
\hline Male & $2,394(50.3)$ & $72(50.3)$ & \\
\hline Female & $2,366(49.7)$ & $71(49.6)$ & \\
\hline \multicolumn{3}{|l|}{ Low birth weight } & \multirow[t]{3}{*}{0.034} \\
\hline No & $4,370(91.7)$ & $124(86.7)$ & \\
\hline Yes & $395(8.3)$ & $19(13.3)$ & \\
\hline \multicolumn{3}{|l|}{ Preterm Birth } & \multirow[t]{3}{*}{0.424} \\
\hline No & $4,079(85.6)$ & $119(83.2)$ & \\
\hline Yes & $686(14.4)$ & $24(16.8)$ & \\
\hline \multicolumn{3}{|l|}{ Congenital Malformations* } & \multirow[t]{3}{*}{0.290} \\
\hline No & 4,701 (98.9) & $140(97.9)$ & \\
\hline Yes & $54(1.1)$ & $3(2.1)$ & \\
\hline Total & $4,765(100)$ & $143(100)$ & \\
\hline
\end{tabular}

Low birth weight: birth weight $<2500 \mathrm{~g}$. Preterm birth: gestational age $<259$ days. ${ }^{*}$ Excluded cases. 
Table 4 Crude and adjusted risks of low birth weight, according to caffeine consumption. Ribeirão Preto Birth Cohort of 2010

\begin{tabular}{|l|l|l|l|l|l|}
\hline \multirow{2}{*}{ Caffeine consumption } & Crude Relative Risk & \multicolumn{4}{l|}{ Adjusted Relative Risk } \\
\cline { 3 - 6 } & & Model 1 & Model 2 & Model 3 & Model 4 \\
\cline { 2 - 6 } & RR (95\% CI) & RR1 (95\% Cl) & RR2 (95\% CI) & RR3 (95\% CI) & RR4 (95\% CI) \\
\hline Not consumed & 1 & 1 & 1 & 1 & 1 \\
\hline$<300 \mathrm{mg} /$ day & $0.91(0.77-1.06)$ & $1.10(0.93-1.32)$ & $1.07(0.91-1.27)$ & $1.08(0.91-1.27)$ & $1.10(0.92-1.32)$ \\
\hline$\geq 300 \mathrm{mg} /$ day & $1.45(0.91-2.32)$ & $1.52(0.92-2.52)$ & $1.56(0.97-2.50)$ & $1.34(0.53-2.16)$ & $1.42(0.85-2.38)$ \\
\hline
\end{tabular}

Abbreviations: $\mathrm{Cl}$, confidence interval; $\mathrm{RR}$, relative risk.

Model 1 adjusted for maternal age, education and skin color, marital status, and occupation of the head of the family.

Model 2 adjusted for parity, previous preterm birth, abortion, and stillbirth.

Model 3 adjusted for gestational hypertension and diabetes, threatened abortion and preterm delivery, alcohol consumption, maternal smoking, and urinary tract infection.

Model 4 adjusted for all variables included in the previous models.

Table 5 Crude and adjusted risks of preterm birth according to caffeine consumption. Ribeirão Preto Birth Cohort of 2010

\begin{tabular}{|c|c|c|c|c|c|}
\hline \multirow[t]{3}{*}{ Caffeine consumption } & \multirow{2}{*}{$\begin{array}{l}\text { Crude Relative } \\
\text { Risk }\end{array}$} & \multicolumn{4}{|c|}{ Adjusted Relative Risk } \\
\hline & & Model 1 & Model 2 & Model 3 & Model 4 \\
\hline & RR (95\% CI) & RR1 (95\% Cl) & RR2 (95\% CI) & RR3 (95\% Cl) & RR4 (95\% Cl) \\
\hline Not consumed & 1 & 1 & 1 & 1 & 1 \\
\hline$<300 \mathrm{mg} /$ day & $0.99(0.87-1.13)$ & $1.07(0.94-1.22)$ & $1.10(0.97-1.25)$ & $1.11(0.97-1.26)$ & $1.10(0.96-1.26)$ \\
\hline$\geq 300 \mathrm{mg} /$ day & $1.16(0.77-1.75)$ & $1.16(0.74-1.80)$ & $1.12(0.73-1.69)$ & $1.12(0.72-1.73)$ & $1.03(0.65-1.63)$ \\
\hline
\end{tabular}

Abbreviations: $\mathrm{Cl}$, confidence interval; RR, relative risk.

Model 1 adjusted for maternal age, education and skin color, marital status, and occupation of the head of the family.

Model 2 adjusted for parity, previous preterm birth, abortion, and stillbirth.

Model 3 adjusted for gestational hypertension and diabetes, threatened abortion and preterm delivery, alcohol consumption, maternal smoking, urinary tract infection and odontological treatments during pregnancy.

Model 4 adjusted for all variables included in the previous models.

models, but without association with high caffeine intake during pregnancy (-Table 5).

\section{Discussion}

In the present study, $64.5 \%$ of the pregnant women drank coffee and there was no difference per trimester of caffeine intake. Only $2.9 \%$ of these women reported high caffeine intake, without association with LBW or preterm birth.

Similarly to the present study, large studies that incorporated trimester-specific questionnaires showed no difference between the trimesters. ${ }^{24}$

In other studies, the incidence of high caffeine consumption was higher than in Ribeirão Preto $\left(18.9 \%,{ }^{11} 13.5 \%,{ }^{9} 12 \%{ }^{2}\right.$ and $8.3 \%^{27}$ ), possibly by including other sources of caffeine. Another explanation is that when other health risks are present, doctors might discourage caffeine consumption, resulting in a lower coffee intake in contrast with the healthier women. This is supported by the elevated rate of gestational hypertension, diabetes, and urinary tract infection observed in the studied population.

Caffeine consumption from coffee, tea, soft drinks with cola, chocolate, and some medications is frequently described, ${ }^{19}$ including in pregnant women. Previous studies found that a high caffeine intake could be harmful during pregnancy because caffeine crosses the placenta and accumulates in the fetus, decreases blood flow and produces biochemical changes, with smaller BW or shorter GA, and increases abortions and the risk of congenital anomalies. ${ }^{10,13}$

In the present cohort, high caffeine consumption during pregnancy was not associated with LBW or preterm birth, in crude and adjusted models. To study the associations between the independent variables and LBW and preterm birth, odds ratios (ORs) were estimated by using a hierarchized (polytomous) logistic regression model.

Other studies reinforced this finding;,3,6,11,17,28-30 recently, two meta-analyses reported a higher risk of delivering LBW newborns, while no association with preterm delivery was found. ${ }^{31,32}$

However, some authors found an association with different caffeine levels (consumption between 70-92 mg/day, ${ }^{30}$ $>300 \mathrm{mg} /$ day, ${ }^{16,21,22,33} \geq 140 \mathrm{mg} /$ day $^{9}{ }^{9}$ and $\geq 6$ cups, with $90 \mathrm{mg} / \mathrm{cup}){ }^{7}$ but most of the associations were found with the highest levels of consumption. ${ }^{31}$

Associations between lower values of caffeine intake and LBW were found in some studies, which divided the cutoff points into between 1 and $100 \mathrm{mg} /$ day, between 101 and 200 $\mathrm{mg} /$ day, and between 201 and $300 \mathrm{mg} /$ day. ${ }^{16,21}$ 
The only existing randomized controlled trial that studied the effect of caffeine on a Danish cohort of 1,207 women during the second half of pregnancy observed no effect on BW or GA at birth. ${ }^{34}$ Another case control study with 502 mothers did not find any association between caffeine intake and preterm birth. ${ }^{3}$

Several recognized maternal conditions were statistically associated with LBW and preterm birth, such as not having a partner, highest parity, previous preterm birth or stillbirth, gestational hypertension, threatened preterm birth, and smoking, in accordance with other studies. ${ }^{27,28}$

High caffeine intake was significantly associated with reduced education, occupation of the head of the family, nonwhite skin color, not having a partner, higher parity, previous abortion and preterm birth, urinary tract infection, threatened abortion, alcohol consumption, and smoking.

Pacheco et $\mathrm{al}^{27}$ found that high caffeine intake was associated with reduced education, higher parity, alcohol consumption, and smoking. No association with age, previous preterm birth, and body mass index (BMI) was found.

Another study with 7,025 women found similar results: women without partner, reduced education, higher parity, history of preterm birth, and smoking presented a higher caffeine intake. $^{30}$

The main differences with other studies were the heterogeneity of the caffeine exposure in different concentrations, of the diversity of brands, of the preparation according to each region and country, of the different methods for the assessment of caffeine consumption (postpartum questionnaires or caffeine concentration in plasma and in saliva measured by swab), of the inadequate measures of caffeine intake, of the insufficient statistical power and control of confounding variables. In some studies, higher consumption of caffeine intake was found with a similar cutoff ( $>300 \mathrm{mg}$ / day), but including tea, chocolate and other sources of caffeine. $^{15,27}$

Some studies suggest a possible effect of chemicals present in coffee and tea other than caffeine, such as polyphenols, which contribute to adverse pregnancy outcomes including preterm delivery and preeclampsia. ${ }^{35}$ Therefore, studies investigating the effect of caffeine tend to overlook the fact that other components in coffee and tea may be contributing factors.

Several limitations of the present study should be mentioned. First, the sample size was originally not computed for caffeine consumption and, therefore, a type I error cannot be ruled out. Second, caffeine intake during pregnancy was measured on a self-reported basis only after birth, a fact known to underestimate the frequency and amount of caffeine ingested by pregnant women; consequently, our study is subjected to recall bias. The information about caffeine intake were obtained by questionnaires; therefore, it was not possible to quantify neither the concentration, the brand of coffee, nor the method of preparation (strong, medium, weak). The questionnaires employed did not have information about other sources of caffeine, such as tea, soft drinks with cola, chocolate, or some medications, which can influence the lower prevalence of consumption of caffeine compared with the aforementioned studies. Third, the present study was performed in a cohort of relatively healthy pregnant women with singleton pregnancies. Therefore, the findings can only be generalized to an obstetric population with a similar risk of complications. Finally, we cannot exclude the possibility of residual confounding variables.

The strength of the present study was the assessment of a birth cohort followed-up since the prenatal period with a high response rate (96\%). Since the data were collected at two different periods, we were able to confirm the information and to adjust the outcomes for a wide range of known confounders, such as maternal behaviors and sociodemographic factors, and possible risk factors of adverse perinatal outcomes could be registered.

Therefore, more detailed studies analyzing sources of caffeine are necessary, and also to verify if any specific trimester of gestation can be more vulnerable to caffeine exposure.

\section{Conclusion}

High caffeine intake during pregnancy was not associated with an increased risk of LBW and preterm risk in the birth cohort of Ribeirão Preto.

\section{Contributions}

All the authors participated in the selection of the theme, in the gathering of references and in the study design. Fernanda Vitti performed the data collection and wrote the article. Carlos Grandi performed the data analysis and the interpretation of the results. Ricardo de Carvalho Cavalli, Vanda Maria Ferreira Simões and Rosângela Fernandes Lucena Batista reviewed the article, and all the authors gave their approval of the final version. Viviane Cunha Cardoso guided the other authors through the interpretation of the data and performed a critical review.

\section{Conflicts of Interest}

The authors have no conflicts of interest to declare.

\section{Acknowledgments}

The present study was funded by the Coordenação de Aperfeiçoamento de Pessoal de Nivel Superior (CAPES, in the Portuguese acronym) and by the Fundação de Amparo à Pesquisa do Estado de São Paulo (FAPESP, in the Portuguese acronym), under the process number 2008/53593-0.

\section{References}

1 Nawrot P, Jordan S, Eastwood J, Rotstein J, Hugenholtz A, Feeley M. Effects of caffeine on human health. Food Addit Contam 2003;20 (01):1-30 Doi: 10.1080/0265203021000007840

2 Clausson B, Granath F, Ekbom A, et al. Effect of caffeine exposure during pregnancy on birth weight and gestational age. Am J Epidemiol 2002;155(05):429-436 Doi: 10.1093/aje/155.5.429

3 Chiaffarino F, Parazzini F, Chatenoud L, et al. Coffee drinking and risk of preterm birth. Eur J Clin Nutr 2006;60(05):610-613 Doi: 10.1038/sj.ejcn.1602358 
4 Maslova E, Bhattacharya S, Lin SW, Michels KB. Caffeine consumption during pregnancy and risk of preterm birth: a metaanalysis. Am J Clin Nutr 2010;92(05):1120-1132 Doi: 10.3945/ ajcn.2010.29789

5 Pastore LM, Savitz DA. Case-control study of caffeinated beverages and preterm delivery. Am J Epidemiol 1995;141(01):61-69 Doi: 10.1093/oxfordjournals.aje.a117346

6 Berkowitz GS, Holford TR, Berkowitz RL. Effects of cigarette smoking, alcohol, coffee and tea consumption on preterm delivery. Early Hum Dev 1982;7(03):239-250 Doi: 10.1016/03783782(82)90086-X

7 Bakker R, Steegers EA, Obradov A, Raat H, Hofman A, Jaddoe VW. Maternal caffeine intake from coffee and tea, fetal growth, and the risks of adverse birth outcomes: the Generation R Study. Am J Clin Nutr 2010;91(06):1691-1698 Doi: 10.3945/ajcn.2009. 28792

8 van der Hoeven T, Browne JL, Uiterwaal CSPM, van der Ent CK, Grobbee DE, Dalmeijer GW. Antenatal coffee and tea consumption and the effect on birth outcome and hypertensive pregnancy disorders. PLoS One 2017;12(05):e0177619 Doi: 10.1371/journal. pone. 0177619

9 Vlajinac HD, Petrović RR, Marinković JM, Sipetić SB, Adanja BJ. Effect of caffeine intake during pregnancy on birth weight. Am J Epidemiol 1997;145(04):335-338 Doi: 10.1093/oxfordjournals. aje.a009110

10 Godel JC, Pabst HF, Hodges PE, Johnson KE, Froese GJ, Joffres MR. Smoking and caffeine and alcohol intake during pregnancy in a northern population: effect on fetal growth. CMAJ 1992;147(02): 181-188

11 Bicalho GG, Barros Filho AdeA. Peso ao nascer e influência do consumo de cafeína. Rev Saude Publica 2002;36(02):180-187 Doi: $10.1590 /$ S0034-89102002000200010

12 Koren G. Caffeine during pregnancy? In moderation. Can Fam Physician 2000;46:801-803

13 Kirkinen P, Jouppila P, Koivula A, Vuori J, Puukka M. The effect of caffeine on placental and fetal blood flow in human pregnancy. Am J Obstet Gynecol 1983;147(08):939-942 Doi: 10.1016/00029378(83)90250-8

14 Camargo MC, Toledo MC, Farah HG. Caffeine daily intake from dietary sources in Brazil. Food Addit Contam 1999;16(02):79-87 Doi: 10.1080/026520399284244

15 Caan BJ, Goldhaber MK. Caffeinated beverages and low birthweight: a case-control study. Am J Public Health 1989;79(09): 1299-1300

16 Srisuphan W, Bracken MB. Caffeine consumption during pregnancy and association with late spontaneous abortion. Am J Obstet Gyneco 1986;154(01):14-20 Doi: 10.1016/0002-9378(86)90385-6

17 Olsen J, Overvad K, Frische G. Coffee consumption, birthweight, and reproductive failures. Epidemiology 1991;2(05):370-374 Doi: 10.1097/00001648-199109000-00011

18 Mills JL, Holmes LB, Aarons JH, et al. Moderate caffeine use and the risk of spontaneous abortion and intrauterine growth retardation. JAMA 1993;269(05):593-597

19 Higdon JV, Frei B. Coffee and health: a review of recent human research. Crit Rev Food Sci Nutr 2006;46(02):101-123 Doi: 10.1080/10408390500400009

20 Fenster L, Eskenazi B, Windham GC, Swan SH. Caffeine consumption during pregnancy and fetal growth. Am J Public Health 1991; 81(04):458-461 Doi: 10.2105/AJPH.81.4.458

21 Martin TR, Bracken MB. The association between low birth weight and caffeine consumption during pregnancy. Am J Epi- demiol 1987;126(05):813-821 Doi: 10.1093/oxfordjournals.aje. a114718

22 Kaiser L, Allen LH; American Dietetic Association. Position of the American Dietetic Association: nutrition and lifestyle for a healthy pregnancy outcome. J Am Diet Assoc 2008;108(03): 553-561 Doi: 10.1016/j.jada.2008.01.030

23 Cardoso VC, Simões VMF, Barbieri MA, et al. Profile of three Brazilian birth cohort studies in Ribeirão Preto, SP and São Luís, MA. Braz J Med Biol Res 2007;40(09):1165-1176 Doi: 10.1590/ S0100-879 × 2006005000148

24 CARE Study Group. Maternal caffeine intake during pregnancy and risk of fetal growth restriction: a large prospective observational study. BMJ 2008;337:a2332 Doi: 10.1136/bmj.a2332

25 Olsen J, Frische G. Social differences in reproductive health. A study on birth weight, stillbirths and congenital malformations in Denmark. Scand J Soc Med 1993;21(02):90-97 Doi: 10.1177/ 140349489302100206

26 von Elm E, Altman DG, Egger M, Pocock SJ, Gøtzsche PC, Vandenbroucke JP; STROBE Initiative. Strengthening the Reporting of Observational Studies in Epidemiology (STROBE) statement: guidelines for reporting observational studies. BMJ 2007;335 (7624):806-808 Doi: 10.1136/bmj.39335.541782.AD

27 Pacheco AHRN, Araujo DMR, Lacerda EMA, Kac G. [Caffeine consumption by pregnant women selected from a Health Care Center in the municipality of Rio de Janeiro, Brazil]. Rev Bras Ginecol Obstet 2008;30(05):232-240 Doi: 10.1590/S010072032008000500005

28 Santos IS, Victora CG, Huttly S, Carvalhal JB. Caffeine intake and low birth weight: a population-based case-control study. Am J Epidemiol 1998;147(07):620-627 Doi: 10.1093/oxfordjournals. aje.a009502

29 Pacheco AHRN, Barreiros NSR, Santos IS, Kac G. Consumo de cafeína entre gestantes e a prevalência do baixo peso ao nascer e da prematuridade: uma revisão sistemática. Cad Saude Publica 2007; 23(12):2807-2819 Doi: 10.1590/S0102-311 × 2007001200002

30 Fortier I, Marcoux S, Beaulac-Baillargeon L. Relation of caffeine intake during pregnancy to intrauterine growth retardation and preterm birth. Am J Epidemiol 1993;137(09):931-940 Doi: 10.1093/oxfordjournals.aje.a116763

31 Chen LW, Wu Y, Neelakantan N, Chong MFF, Pan A, van Dam RM. Maternal caffeine intake during pregnancy is associated with risk of low birth weight: a systematic review and dose-response meta-analysis. BMC Med 2014;12:174-185 Doi: 10.1186/ s12916-014-0174-6

32 Greenwood DC, Thatcher NJ, Ye J, et al. Caffeine intake during pregnancy and adverse birth outcomes: a systematic review and dose-response meta-analysis. Eur J Epidemiol 2014;29(10): 725-734 Doi: 10.1007/s10654-014-9944-X

33 Peacock JL, Bland JM, Anderson HR. Effects on birthweight of alcohol and caffeine consumption in smoking women. J Epidemiol Community Health 1991;45(02):159-163

34 Bech BH, Obel C, Henriksen TB, Olsen J. Effect of reducing caffeine intake on birth weight and length of gestation: randomised controlled trial. BMJ 2007;334(7590):409 Doi: 10.1136/ bmj.39062.520648.BE

35 Sengpiel V, Elind E, Bacelis J, et al. Maternal caffeine intake during pregnancy is associated with birth weight but not with gestational length: results from a large prospective observational cohort study. BMC Med 2013;11:42-59 Doi: 10.1186/17417015-11-42 